Tax Morale, Tax Evasion, and the Shadow Economy

Gebhard Kirchgässner

May 2010 Discussion Paper no. 2010-17 


$\begin{array}{ll}\text { Editor: } & \text { Martina Flockerzi } \\ & \text { University of St. Gallen } \\ & \text { Department of Economics } \\ & \text { Varnbüelstrasse 19 } \\ & \text { CH-9000 St. Gallen } \\ & \text { Phone } \quad+41712242325 \\ & \text { Fax } \quad+41712243135 \\ & \text { Email vwaabtass@unisg.ch } \\ & \text { Department of Economics } \\ & \text { University of St. Gallen } \\ & \text { Varnbüelstrasse 19 } \\ \text { Publisher: } & \text { CH-9000 St. Gallen } \\ & \text { Phone +41 71 224 23 25 } \\ & \text { Fax } \quad+41712243135 \\ & \text { http://www.vwa.unisg.ch }\end{array}$




\title{
Tax Morale, Tax Evasion, and the Shadow Economy
}

\author{
Gebhard Kirchgässner ${ }^{1}$
}

Author's address: $\quad$ Prof. Dr. Gebhard Kirchgässner

SIAW-HSG

Bodanstrasse 8

$\mathrm{CH}-9000$ St.Gallen

Phone $\quad+41712242340$

Fax $\quad+41712242298$

Email gebhard.kirchgaessner@unisg.ch

Website www.siaw.unisg.ch

\footnotetext{
${ }^{1}$ Universität St. Gallen, Schweizerisches Institut für Aussenwirtschaft und Angewandte Wirtschaftsforschung, Leopoldina und CESifo.
} 


\begin{abstract}
Under which conditions is moral justification of taxation possible? This question does not only interest philosophers and economists from a scientific point of view, but can have considerable practical relevance as well because the willingness of citizens to pay taxes may depend upon whether they consider taxation to be morally justified or not. We first consider theoretical arguments on the role of tax morale, and when tax evasion might be considered as justified by citizens or not. Then we ask how tax morale can be measured. Next, we discuss the role of tax morale for the shadow economy, before determinants of tax morale and empirical results for the impact of tax morale on tax compliance are discussed. For a high tax morale, institutional and cultural factors are at least as important as economic incentives.
\end{abstract}

\title{
Keywords
}

Tax morale, tax evasion, principles of taxation, trust, direct democracy, federalism

\section{JEL Classification}

$\mathrm{H} 2 \mathrm{O}, \mathrm{H} 26$ 


\section{Introduction}

[1] Following a usual distinction, the shadow economy can be divided into three parts: (i) pure tax evasion, i.e., legal activities are legally performed but no taxes are paid; (ii) the black economy, where legal activities are illegally performed; and (iii) criminal, i.e., illegal activities. ${ }^{1)}$ Taxes are evaded not only in the first area, but also whenever activities are illegally performed. Thus, activities in the shadow economy are always connected with tax evasion, and factors influencing the latter will also always have an impact on the former.

[2] If we put to one side financial psychology which has been all but forgotten today, ${ }^{2)}$ moral factors have scarcely been taken into account when the behaviour of taxpayers has been analysed. ${ }^{3)}$ Following the economic theory of criminal behaviour the extent to which citizens pay or evade taxes depends on a simple cost-benefit calculus: The additional income by not paying taxes is compared with the expected punishment, i.e., the product of the expected punishment and the probability that this punishment will be executed. ${ }^{4)}$ As many investigations show, this model identifies two important factors, but is unable to explain the behaviour of taxpayers: given the low probability of detection citizens should pay much less tax than they actually do. ${ }^{5)}$

[3] In order to correctly pay their taxes, individuals must have a motivation which includes more than the simple economic calculus; other factors also play an important role. If we still assume that citizens' behaviour is rational, it has to be moral behaviour. ${ }^{6}$ ) Thus, it is not by chance that we speak of tax morale, i.e., we assume that citizens consider it - under certain circumstances - as being their moral duty to pay their taxes even if - from a purely economic point of view - it would be profitable to try to evade them.

[4] As R.W. McGeE (2006) shows with reference to M.T. CROwE (1944), there exist three ethical (moral) positions with respect to tax evasion: (i) it can be judged as being categorically unethical, i.e., there is no justification at all for tax evasion; (ii) it is generally allowed, be-

1. On the definition of the shadow or underground economy see, for example, G. KIRCHGÄSSNER (1984, p. 379).

2. On financial psychology see, for example, G. SCHMÖLDERS (1981).

3. There is, for example, only a rather small section on moral aspects of taxpayer behaviour in the survey on tax compliance by J. ANDREONI, B. ERARD and J. FEINSTEIN (1998). The substantial literature on financial psychology is totally neglected. For an overview of earlier contributions to tax morality see also E. SCHÖBEL (2005).

4. On the (traditional) economic theory of tax evasion see, for example, V. TANZI (1993), the classical contribution by M.G. AlLingham and A. SANDMO (1972) as well as W. Richter (2010).

5. This holds, at least as long as we do not assume extreme risk aversion. See, for this, for the United States J. Alm, G.H. McClelland and W.D. Schulze (1992), or for Switzerland W.W. Pommerehne and H. WECK-HANNEMANN (1996). M.J. GRAETZ and L.L. WiLDE (1985) call the statement that tax evasion is a good example to apply the economic theory of criminal behaviour a "myth".

6. On the definition of moral behaviour see G. KIRCHGÄSSNER (2010). 
cause the government is viewed as a thief which confiscates assets; and (iii) that whether tax evasion is ethical or unethical depends on the concrete circumstances. To the latter belong, for example, whether the tax system is considered as fair or unfair, what is done with the tax revenue, and as first mentioned by H. WECK-HANNEMANN and W.W. POMMEREHNE (1989), how far taxpayers can influence what is done with their tax money. ${ }^{7}$ )

[5] What is, however, 'tax morale', and how can it be measured? In the German-speaking countries in particular, there is often a misunderstanding because tax morale is (largely) equated with tax compliance. But while the former is a moral attitude, the latter is concrete behaviour, and both do not necessarily coincide. In the following, we first consider theoretical arguments on the role of tax morale, and under which conditions tax evasion might be considered to be justified by citizens or not (Section 2). Then we ask how tax morale can be measured (Section 3). In Section 4, we discuss the role of tax morale for the shadow economy. In Section 5, determinants of tax morale and in Section 6, empirical results of the effects of tax morale on tax compliance are discussed. The results show that for a high tax morale, institutional and cultural factors are at least as important as economic incentives. We conclude with some remarks on citizens' duties (Section 7).

\section{Theoretical Considerations}

[6] As mentioned above, tax morale regards the question to what extent citizens consider it their moral duty to pay taxes. Considering it as a moral duty supposes that there are justified reasons to pay taxes besides the legalistic ones. What these reasons are, i.e., under which conditions paying taxes can be considered as the moral duty of citizens (and under which conditions tax evasion might be justified) is not only a problem discussed in economics, but has also been discussed for a long time in philosophy and, in particular, in theology.

[7] Taxes are prices for the goods and services provided by the government. The relevant question for the moral evaluation of taxes is whether this price corresponds to the value of these services, i.e., whether it is 'just' in this sense. This approach of the 'just price' also holds for the principles of taxation developed in the nineteenth century which today are still to be found in textbooks of public finance, especially the equivalence principle, but also the ability-to-pay principle. ${ }^{9)}$ The fact that these services are not distributed via a market and that, therefore, no market price exists made a simple transfer of the marginalist principle scarcely

7. See for this also B. TORGLER (2005).

8. See for this also G. KIRCHGÄSSNER (2003, pp. $221 \mathrm{ff}$.).

9. See, for example, R.A. Musgrave and P.B. Musgrave (1984, pp. 227ff.). - The basic considerations can be traced back to the Nicomachean Ethics (1131a, p. 106) of ARISTOTLE who, when discussing his concept of 'particular justice', distinguishes between a 'balancing' and a 'distributing' justice, depending on whether the exchange of goods is discussed or the distribution of means within a community. (See for this, for example, R. HAUSER (1974, p. 330.)) This distinction is taken up by THOMAS AQUINAS in his Summa Theologica (III, 58ff., pp. 254ff.), in which he distinguishes between a 'justitia commutativa' and a 'justitia distributiva' (as well as a 'justitia legalis‘). (See R. HAUSER (1974, p. 333.)) 
possible. Consequently, the original formulations of the principles of just taxation refer rather to the average costs of the services which are publicly provided. ${ }^{10)}$

[8] That with respect to this problem - as is often the case in economic ethics - the discussion is based on the idea of the just price and, therefore, on the concept of exchange justice, has first of all a practical reason: similarly as regards the Pareto principle which, however, is much less far-reaching, there is no serious dispute about it. In a specific situation it might be difficult to determine what the real value of the goods or services to be exchanged is, but that any exchange should follow the principle that taking and giving should be equivalent is hardly ever disputed. $^{11)}$

[9] With respect to exchange justice both sides have to be considered. The supplier of a good should get a price which covers at least his (justified) costs. This also holds for those services which are publicly provided. Thus, public employees have to earn an acceptable (just) wage, but the price should not be too high, because public providers are wasting resources at their disposal, in particular taxpayers' money. Those who use publicly provided services have, first, the right to only pay for those services they are interested in and, second, not to pay too high a price. The tax price might, however, be different for different individuals, depending, for example, on their income. Perhaps this should even be the case for going along with the principle of vertical justice because the willingness to pay for these services might - ceteris paribus - be a positive function of their income. ${ }^{12)}$ This makes it possible that - in principle all citizens can agree to the package of services and taxes provided by the government. ${ }^{13)}$ This leads, in principle, to lower and upper limits of the costs of publicly provided services and at least also to an upper limit of the extent of publicly provided services. ${ }^{14)}$

[10] Following these considerations, levying taxes is morally justified and, therefore, paying taxes a moral duty, only as long as those services are publicly provided, for which such a demand exists on the part of the citizens and if these services are provided efficiently. In all

10. On the history of the ability-to-pay principle see, for example, W. KocH (1981, pp. 225ff.). Independent of this discussion, however, for the goods of public enterprises marginal cost prices have been advocated in modern public finance. See for this, for example, CH. B. BLANKART (1980, pp. $21 \mathrm{ff}$.).

11. See for this O. HöFFE (1990, pp. 92f.), but also O. HöFFE (1987, pp. 382ff.; 1994). He considers the principle of exchange justice as being a general principle of justice which also might be transferred to the political area. He complements it, however, with a principle of corrective justice. See for this O. HöFFE (1994).

12. For the distinction between horizontal and vertical justice in relation to the ability-to-pay principle see, for example, R.A. MusGrAVE and P.B. MusGrAVE (1984, pp. 232f.).

13. This has already been mentioned by K. WiCKSELL (1986). J.M. BUCHANAN based his approach of 'Constitutional Economics' on this idea assuming that - in principle - it should be possible to reach such a general consensus. See for this J.M. BUCHANAN (1967, pp. 114ff.) as well as J.M. BUCHANAN (1987).

14. There are also arguments in favour of a lower limit of these services. (See, for example, J. GALBRAITH (1958) and his arguments about "public poverty and private wealth".) Taking into account the strong increase of the government share since the sixties this might today, however, be of secondary importance in the developed industrial countries of the Western world. 
other cases tax evasion might be punished, but from the perspective of the just exchange paying taxes is not a moral duty. ${ }^{15)}$

[11] These considerations are mainly based on the equivalence principle. They are not only relevant for the supply of public goods but also for the redistribution organised by the government as long as this redistribution can be interpreted as being voluntary or as an insurance against risks in cases where no private insurance exists (or private insurance cannot be supplied without making deficits). ${ }^{16)}$ For such situations, one might take on the perspective of the original position in J. RAWLS (1971). According to this approach, publicly provided services and their financing by publicly forced payments can be justified whenever the individuals behind the veil of ignorance decide that it has to be done in this manner. How far this holds for the redistribution actually performed today is, however, open. As the discussion following the publication of his "Theory of Justice" has shown, there is a large distance between redistribution according to the difference principle of J. RAWLS (1971) and the utilitarian principle of expected utility maximisation favoured, for example, by J.C. HARSANYI (1975). This distance is scarcely narrowed down if we employ the concept of the original position, in particular, if we assume risk neutrality when applying the expected utility maximisation principle. ${ }^{17}$ Whichever principle we use, however, it always holds that using the concept of the original position taxation can be justified even if there is no exact equivalent for every individual. Moreover, J. RAWLS (1971) provides sound arguments that individuals in the original position would choose the (or a variant of the) ability-to-pay principle with progressive income taxation. Following these arguments this principle can also be justified by the idea of just exchange. This is not contradicted by the fact that, when discussing problems of taxation, J. RAWLS (1971, pp. 245ff.) does not refer to the traditional taxation principles but only to his difference principle, and that he argues that - under certain conditions - even a proportional income taxation might be compatible with this principle. On the other hand, he also mentions: "It does not follow that, given the injustice of existing institutions, even steeply progressive income taxes are not justified when all things are considered." The question of whether the income tax tariff should be progressive or not is for him a question "of political judgement and not part of the theory of justice" (pp. 246f.). The concept of a regressive income tax would, on the other hand, violate his ideas of justice and is, therefore, not considered at all.

15. Insofar as tax laws are pure 'penal laws', the government might force citizens to obey, but it does not bind their consciousness. As G. SCHMÖLDERS (1951, pp. 18f.) shows, the moral theory of the Scholastic already knows this conception.

16. Following H.-W. SINN (1997) most of the services provided by governments can be interpreted as being just such insurances, i.e., it does not only hold for explicit redistribution, but also for publicly provided goods and services. Moreover, these public services do only to a small extent crowd out private insurances because "the by far largest part of the social security system covers risks for which no private insurance is available" (H.-W. SINN (1996, pp. 263)). This does not, however, imply that (all) individuals would voluntarily take out such an insurance. For the discussion of arguments in favour of voluntary redistribution see, for example, G. KIRCHGÄSSNER and W.W. POMMEREHNE (1992). For the relevance of distributive justice for tax compliance see also P. VERBOON and M. VAN DIJKE (2007).

17. For the presentation of the two principles see, for example, B.S. FreY and G. KIRCHGÄSSNER (2002, pp. 35f., pp. 262ff.). 
[12] A progressive income tax might, on the other hand, also be justified if the citizens do not (only) take their absolute income into account but their relative income as well, i.e., if they compare their own income with that of their fellow citizens. ${ }^{18)}$ Empirical results show that this usually holds. ${ }^{19)}$ This also holds for Switzerland. ${ }^{20)}$ Moreover, theory of optimal taxation shows that under this condition higher marginal tax rates and, therefore, a progressive income tax schedule, is also appropriate for efficiency reasons. ${ }^{21)}$

[13] When applying the concept of the original position the two conditions mentioned above still hold: paying taxes is a moral obligation only as far as the citizens (in the situation of the original position) demand that the corresponding services are publicly provided and as long as these are efficiently provided. Under these conditions evading taxes is breaking a contract and might morally be qualified as being similar to theft. On the other hand, if these conditions are violated, levying taxes is an illegitimate infringement of the property of the citizens concerned and might also be morally qualified as theft.

[14] Such considerations can also be performed with respect to the concept of a 'fair tax system'. Citizens feel themselves more justified, the less they perceive the tax system as fair. New developments of economic theory have shown that arguments of fairness which traditionally have been considered as being unimportant have strong impacts on the behaviour of people. ${ }^{22)}$ This holds, as shown below, in particular in the area of taxes. ${ }^{23)}$ If tax compliance is to be high, one of the most important aspects is that the tax system should be perceived by the citizens as fair (or at least that it can be perceived as being fair).

[15] But it is not only the fairness of the tax system itself but also the trust in the political and legal system which matters. Citizens have to trust their political representatives and the tax bureaucrats to use the tax revenue responsibly. And they should have trust in the legal system that they will be fairly treated should they ever have a dispute with the tax authorities. Otherwise, they will hardly perceive paying taxes as a moral duty. Correspondingly, $\mathrm{H}$. HAMmar, S.C. Jagers and K. NordblOM (2009, p. 238) conclude that "it is important for politicians to be perceived as trustworthy in order to be able to collect taxes".

[16] How people evaluate these questions also depends on the (religious) tradition or the traditional relation between political and religious authorities in the countries. It is to be noticed

18. See for this A. BALESTRINO (2009).

19. See, for example, R. EASTERLIN (2001).

20. See for this D. DoRn et al. (2008).

21. See for this M. BoSKIN and E. SHESHINSKI (1978) as well as N. IRELAND (2001).

22. See, for example, D. Kahnemann, J.L. Knetsch and R.H. Thaler (1986), J. Broome (1990), J. Konow (2003) or B. HOOKER (2005).

23. See, for example, M. Bordignon (1993) or M. ViHANTO (2003). 
that tax morale is considerably lower in the Romanic compared to the Nordic countries. ${ }^{24)}$ This apparently reflects a different attitude towards the government. One reason for this might lie in the different religious traditions. Since the Middle Ages, in the Romanic, mostly Catholic countries, there have quite often been disputes between the government and the church, i.e., between political and religious authorities which, for example, were rather vigorous in France and Italy at the end of the eighteenth and in the nineteenth centuries. Partly, as for example in the Investiture Controversy, it was forbidden by the Church to support the political authorities. In the Nordic countries, which, on the other hand, had a nearly completely Protestant population, political and religious authorities had been unified since the Reformation; the king was not only the supreme political authority but also the head of the state church, which partly (at least in a formal sense) still holds today. Thus, an offence against the government was also a religious offence: a sin. This had a strong impact on the population in these countries, and there was no abrupt change in this respect once the importance of religion in public (and private) life declined. Seen from this perspective it becomes understandable that - ceteris paribus - tax evasion is more strongly pronounced in southern compared to northern Europe. $^{25)}$

[17] The opinions of citizens on how far these two conditions are fulfilled and, therefore, whether paying taxes is a moral duty differ also largely within the different societies. As we are never really in the situation of the original position but are always in the ongoing political process citizens might be strongly influenced by their social positions as well as their income. Insofar as this may be the case, it is hardly possible to concede single individuals an individual right of resistance which allows them to take their own decision to deny payment of taxes, even if some groups sometimes claim such a right for themselves. ${ }^{26)}$ That, on the other side, such considerations of justice play a role in political reality is not only shown by auditing institutions whose role is to fight the waste of tax revenue but also by a decision of the German Constitutional Court in 1995 according to which a tax rate for capital income of more than 50 per cent is not compatible with the German Constitution. ${ }^{27)}$

24. According to the estimates of H. WECK (1983) the index of tax immorality was in 197820.6 in Italy, 17.3 in France and 14.0 in Spain. In Sweden, Denmark and Finland it was, however, only 4.4. Germany and the Netherlands had a middle position with 10.9.

25. This "North-South-gradient of tax morality" is, as G. SCHMÖLDERS (1981, p. 131) shows, also reflected in the languages of the different countries.

26. In the eighties, some German citizens claimed to have a right of resistance in the form of a tax boycott against the use of tax revenue for defence purposes. This claim was rejected by the Financial Court of Cologne in its decision of November 15, 1984 (V K 223/84). See for this P. SELMER (1986).

27. BVerfG 93, 121; 93, 165. The Constitutional Court states the 'principle of property preserving taxation'. See for this K. TIPKE and J. LANG (1973, pp. 121ff.).- For Switzerland, H. KLEINEWEFERS proposed the following article for the constitution: "(1) Each individual has the right to the results of his work and his property. (2) Nobody's current income is to be burdened by direct and indirect publicly forced payments without individually equivalent services in return to more than one half." Thus, he assumes that today this limit is often transgressed. See: H. KLEINEWEFERS, Das vergessene Grundrecht: Für ein Recht auf den Ertrag der eigenen Arbeit und des eigenen Vermögens, Neue Zürcher Zeitung No. 12, January 16, 1999, p. 29. 
[18] The question of how far citizens are able to influence the use of their tax money might also be important for their willingness to pay taxes. The more impact the citizens have on the size of their taxes as well as their usage, the more they can be convinced that they do not have to pay too high taxes and that their taxes are not wasted. Thus, in more direct democracies the willingness to pay taxes might - ceteris paribus - be higher and tax evasion lower compared to purely representative systems. ${ }^{28)}$ The federal structure of a country might have a similar impact. The more decentralised fiscal decisions are, the more influence citizens can exert and the more trust they might have in their political institutions. ${ }^{29)}$

[19] Besides this, the willingness to pay taxes might also depend on the way citizens are treated by the tax authorities. The stronger their feeling that they are treated unfairly the more they believe in having a right to evade taxes. ${ }^{30)}$ Nevertheless, such an attitude is highly problematic because, as long as it is a morally relevant problem, tax evasion is not a problem between the single taxpayer and the tax authority, but between him/her and the community of all citizens. On the other hand, the tax bureaucrats have the (moral) duty to treat taxpayers fairly.

\section{Measuring Tax Morale}

[20] Before we can evaluate the impact of tax morale on tax compliance, we have to measure it. This can be done by surveys. In the International Social Science Panel (ISSP), for example, the following question is employed: ${ }^{31)}$

A taxpayer does not report all of his or her income in order to pay less income taxes. Do you feel it is (i) not wrong, (ii) a bit wrong, (iii) wrong, (iv) seriously wrong?

If we allocate values between 1 and 4 to the different answers, 1 indicating the lowest and 4 the highest tax morale, we get an index with values between 1 and $4 .{ }^{32)}$ Switzerland, for example has a value of 2.65 which is considerably below the average of 2.93 (with a standard deviation of 0.24$)$.

[21] The question in the World Value Survey (WVS) is slightly different: ${ }^{33)}$

28. See for this W.W. Pommerehne, A. Hart and B.S. Frey (1994) as well as W.W. Pommerehne, A. Hart and L.P. FELD (1997).

29. See for this W.E. OATES (1985, p. 749).

30. See also for this - in a more general connection - T.R. TYLER (1997): The more fair the citizens feel they are treated, the more they are prepared to fulfil legal obligations.

31. These date relate to 1998. See: http://www.gesis.org/dienstleistungen/daten/umfragedaten/issp/modulesstudy-overview/religion/1998/ (04/03/10) (question V16 for tax morale).

32. Here, we consider averages of the countries. The whole sample of the ISSP-data comprises 39,034 persons.

33. See R. INGLEHART et al. (2004, question F116). These data, which relate to the years 1999 to 2002, comprises 89,678 persons. 
Please tell me for each of the following statements whether you think it can always be justified, never be justified, or something in between: Cheating on taxes if you have a chance?

Those surveyed were given a 10 point scale where ' 1 ' implied that tax evasion can never and ' 10 ' that it can always be justified. It is again possible to construct an index; its mean is 2.27 with a standard deviation of 0.69 . Switzerland, for example, gets a value of 2.65 and, therefore, ranked 60 out of the 80 countries considered. ${ }^{34)}$

\section{The Role of Tax Morale in the Shadow Economy}

[22] A low tax morale should - ceteris paribus - have the effect of making tax evasion high. Institutional (and other factors) might, however, have the opposite effect. Therefore, a low tax morale does necessarily coincide with high tax evasion. Thus, we have to ask for the effective impact of tax morale on tax compliance, which is an empirical question. To answer this, tax morale has to be recorded independently from tax compliance, and, together with other possible impact factors, should be included in a model which tries to explain the extent of tax evasion.

[23] For the first time, such an investigation was performed by H. WECK $(1983)^{35)}$ where she used, however, not the extent of tax evasion but the size of the shadow economy as dependent variable. To estimate the size of the shadow economy of different countries in order to make an international comparison, she uses the model approach for non-observable variables. It is assumed that there are (measurable) impact factors as well as indicator variables for the nonobservable variable 'size of the shadow economy'. The impact factors are the input variables of the model, they determine the size of the shadow economy, while the indicators are output variables, which allow to measure this size. The model is estimated using the LISREL approach developed by K.G. JÖRESKOG and M. V. THILO (1973) in order to estimate ,linear interdependent structural relationships'. It allows to derive estimates of the size of the shadow economy. $^{36)}$

[24] H. WECK (1983) uses as impact factors the shares of direct taxes $\left(\mathrm{T}_{\text {dir }}\right)$, of indirect taxes $\left(\mathrm{T}_{\text {indir }}\right.$ ), and of social security contributions (SSC) in relation to GDP, the perception of the tax burden, measured by the change of the share of direct taxes $\left(\Delta \mathrm{T}_{\text {dir }}\right)$, the burden of government regulation (REG), measured by the share of public employees in the labour force, real disposable income per capita (YDR), a ten-year-average of the unemployment rate (UR) as well as

34. A more detailed analysis of the data shows that the rank correlation for those 28 countries which are included in both surveys is only 0.546 and, therefore, relatively small. This casts some doubt on the validity of these data. Nevertheless, these surveys provide the only data available for international comparisons.

35. See also B.S. FreY and H. WeCK-HANNEMANn (1984).

36. F. SCHNEIDER calls this the MIMIC (Multiple Indicators Multiple Causes) or DYMIMIC (Dynamic Multiple Indicators Multiple Causes) approach. See, for example, R. DELL' ANNO and F. SCHNEIDER (2006) or F. SCHNEIDER (2005), respectively. 
estimates of the tax morale (TM) from survey data. ${ }^{37)}$ Besides a stochastic term $(\varepsilon)$, these variables determine the size of the shadow economy $(\mathrm{S})$. Indicators are the age adjusted male participation rate (MPR), the effective working time per week (TIME), as well as the growth rate of the - officially reported - GDP (GR $\mathrm{GDP})$, always in addition to a stochastic term $\left(\delta_{\mathrm{i}}, \mathrm{i}=\right.$ 1, 2, 3). Using data for 17 OECD countries and for the years 1960, 1965, 1970, 1975 and 1978 , she estimates the following model: ${ }^{38)}$

(i) The structural model

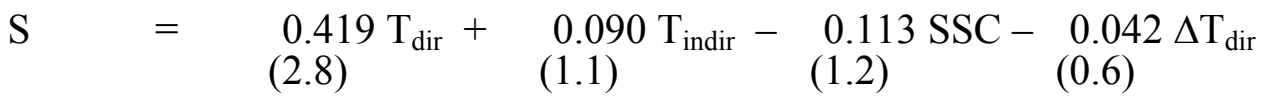

$$
\begin{aligned}
& +0.294 \mathrm{REG}+0.136 \mathrm{YDR}-0.078 \mathrm{UR}-0.480 \mathrm{TM}+\varepsilon \text {. } \\
& \text { (2.4) (1.4) (1.1) (4.5) }
\end{aligned}
$$

(ii) The measurement model

$$
\begin{array}{ll}
\mathrm{MPR}=-0.080 \mathrm{~S}+\delta_{1}, & \mathrm{R}^{2}=0.621, \\
\mathrm{TIME}=-1.000 \mathrm{~S}+\delta_{2}, & \mathrm{R}^{2}=0.419, \\
\mathrm{GR}_{\mathrm{GDP}}=-0.198 \mathrm{~S}+\delta_{3}, & \mathrm{R}^{2}=0.976 . \\
\chi^{2}=61.5, \mathrm{DF}=52 . &
\end{array}
$$

In the structural model, only the burden of direct taxes, the extent of regulation and tax morale have a significant impact. It is important to note that the latter is significantly different from zero at a level less than 0.1 per cent: tax morale has the most significant impact on the size of the shadow economy. Thus, it should be obvious that its impact should not be neglected.

[25] How important this impact is might be demonstrated by comparing two countries in this sample, the Netherlands and Italy. Following B.S. FrEY and H. WECK-HANNEMANN (1984, p. 46), Italy had in 1978 a larger shadow economy (in relation to GDP) than the Netherlands, although the latter had a considerably higher burden of direct taxes of 16.1 per cent and the higher share of public employees of 13.9 per cent. (The corresponding figures for Italy are 10.2 and 13.2 per cent, respectively.) The result is mainly determined by the considerably higher tax morale in the Netherlands. ${ }^{39)}$ Without including this variable it would not make sense to estimate this model. And this implies that it is hardly possible to capture the causes of

37. Actually, she uses an 'index of tax immorality'. For the construction of this variable see H. WECK (1983, p. 91, p. 110) as well as H. WeCK, W.W. POMMEREHNE and B.S. FreY (1984, p. 57.). With respect to its content this does not, however, change anything if it is taken into account that the sign of the coefficient is reversed.

38. See H. WeCK (1983, p. 112) as well as B.S. FrEY and H. WECK-HANNEMANN (1984, p. 40), who use the same model. - The numbers in parentheses are the absolute values of the t-statistics of the estimated parameters. DF is the number of degrees of freedom. The variables are standardised.

39. See for this H. WECK (1983, p. 119, p. 133). To estimate the size of the shadow economies in the different countries only the significant variables of the structural model are used. 
the shadow economy in an international comparative way without taking into account this moral factor. ${ }^{40)}$ Thus, also when using the economic approach, it makes sense and is, in many situations, even necessary to revert to moral attitudes of the population if the size of the shadow economy (and the extent of tax evasion) in a country is to be explained. On the other hand, tax compliance (as well as abidance by other laws) retroact on tax morale. ${ }^{41}$ ) But then a more detailed investigation of tax morale and its determinants seems to be appropriate.

[26] Though its validity is not undisputed, in the last two decades this approach has widely been used to estimate the size of the shadow economy, in particular by F. SCHNEIDER and several collaborators. ${ }^{42)}$ As far as data are available, all these models use tax morale as one of the explanatory variables of the shadow economy. Relating to our question of interest, whether tax morale has an effect on tax evasion (and the activities of the shadow economy) the results of these studies can, however, at best be judged as weak empirical evidence for such a relation but not as results of strict tests. ${ }^{43)}$ The estimated values of the size of the shadow economy are linear combinations of variables including tax morale, i.e., the information included in this indicator is already employed by constructing the dependent variable. It can, therefore, not be used a second time to test whether such a relation exists. Such tests demand estimates of the shadow economy (or the amount of evaded taxes) that are constructed independently of this information.

\section{Determinants of Tax Morale}

[27] What are, however, really the determinants of tax morale, i.e., which of the possible impact factors are not only plausible from a theoretical point of view (and are, perhaps, morally justified), but are also empirically relevant? More recently, quite a lot of investigations have been undertaken, concerning rather different countries as well as societal groups. ${ }^{44)}$ The necessary data have been collected by surveys and experiments; as far as internationally comparative studies are performed the data mentioned above collected in the World Value Survey and the International Social Science Panel have been employed.

40. The estimated coefficients are biased whenever a relevant explanatory variable is excluded from the regression as long as this variable is correlated with the included variables.

41. See for this M. ORVISKA and H. HudSON (2002) as well as M. WENZEL (2005).

42. See, for example, F. Schneider (2005), F. SChneider and D. Enste (2000, 2002), K. Chaudhuri, F. SCHNEIDER, and S. CHATTOPADHYAY (2006), or B. TORGLER and F. SCHNEIDER (2009). - For the debate as to whether this approach is appropriate see, for example, T. BREUSCH (2005) and the response by R. DELL' ANNO and F. SCHNEIDER (2006).

43. This also holds for those papers where (DY)MIMIC estimates derived in other papers are used to explain the size of the shadow economy using usual econometric methods, as long as tax morale is used in the (DY)MIMIC approach to construct the dependent variables employed in these other papers. See, for example, B. TORGLER and F. SCHNEIDER (2009).

44. See, for example, J.T. Scholz and N. Pinney (1995), B. Torgler (2003, 2003a, 2003b, 2004, 2005$)$, B. Torgler and F. Schneider (2007), B. Torgler and CH.A. Schaltegger (2006), S.-Y. WU and M.-J. TENG (2005), or R.W. MCGEE (2005, 2006, 2008). 
[28] Following R.W. MCGEE (2005, p. 27), the fairness of the tax system is one of the most important determinants of a high tax morale. ${ }^{45)}$ It is, for example, more important than the tax burden. Tax evasion is judged more to be morally justified the more unjust and/or corrupt a government is perceived. Those arguments, on the other hand, that do not relate to fairness, are least acceptable as a moral justification of tax evasion.

[29] 'Fairness' is, of course, a broad term that can include quite a lot. If we consider this in more detail, it becomes obvious that reciprocity plays an important role: tax evasion seems to be more morally justified (objectionable) the more others evade taxes as well (comply). ${ }^{46)} \mathrm{Be}-$ sides this, it is important how the taxpayers' money is used, whether it is beneficially spent or futilely wasted, and whether the tax burden is considered appropriate for the services provided by the government. It is obvious that those (moral) arguments discussed in the previous section really play a role for tax morale.

[30] While R.W. MCGEE is concerned with subjective evaluations directly related to the tax system, B. TORGLER considers, aside from individual factors such as age, sex, marital status and employment status, which are not to be discussed here, more general evaluation indicators such as trust in the government and in the legal system. Both have a significantly positive impact on tax morale. ${ }^{47)}$ The same holds for the degree of decentralisation, ${ }^{48)}$ while public sector inefficiency has a negative impact. ${ }^{49)}$ Besides this, cultural factors ${ }^{50)}$ and, in particular, religious behaviour play important roles: religious people have a higher tax morale. ${ }^{51)}$ In his investigation for Canada (2003b, p. 296), Catholics have a lower tax morale than Protestants,

45. The results of R.W. MCGEE (2005a) are based on surveys among members of internationally active manager societies. He obtains very similar results from students of rather different countries. Many of these studies are published in R.W. MCGEE (2008). - On the role of fairness see also A. FoREST and S.M. SHEFFrIN (2002) as well as D.D. BOBECK and R.C. HATFIELD (2003).

46. See for this also B.S. FreY and B. TORGLER (2007).

47. See for this also M. Wenzel (2004), who shows that tax morale is higher, the more citizens identify with their political community, S.-Y. WU and M.-J. TENG (2005) who point to the impact of corruption, as well as I. LAGO-PeÑAS and S. LAGO-PEÑAs (2008) who show that tax morale is higher the higher satisfaction with democracy and trust in politicians is.

48. See for this B. Torgler (2005a), B. Torgler and W. Werner (2005), but also W. GÜth, V. Levati and R. SAUSGRUBER (2005).

49. See for this G. BARONE and S. MOCETTI (2009).

50. See for this, for example, J. Alm and B. TORgLer (2006) or B. TORGLER and F. SCHNeider (2007).

51. See B. TORGLER (2006) in an internationally comparative study covering 30 countries or B.S. FREY and B. TORGLER (2007) looking at several East- and West-European countries. On the relation between tax morale and religiosity in Germany see A. PRINZ (2004) as well as L.P. FeLD, B. TORGLER and B. DONG (2008). A. PRINZ shows that religious attitudes strongly influence tax morale, with a significant difference between West and East Germany. In West Germany religious education seems to be most important, while in East Germany it is personal conviction. L.P. FELD, B. TORGLER and B. DONG (2008) show that church attendance had a positive and highly significant impact on tax morale in 1990 and 1997, while its impact in 1999 was insignificantly negative. This difference casts, however, severe doubts on the validity of these estimates, because it is hardly plausible that the preferences of the German population changed that drastically within only two years. 
but it is open whether the difference is statistically significant. ${ }^{52)}$ On the other hand, the comparative study by J. ALM and B. TORGLER (2006) shows that those indicators which represent cultural factors have a relatively high impact in 'Catholic' countries.

[31] We take the results of B. ToRgLer (2005) for Switzerland as an example. He investigates the impact of direct democratic rights on tax morale. ${ }^{53)}$ Thus, this paper is different from his other studies (as well as the papers in R.W. MCGEE (2008)) insofar as, besides individual attributes, not only are subjective evaluations included in the test equations but so is an 'objective' indicator of the political system. He uses the ISSP data mentioned above. For Switzerland, he has 1,068 observations surveyed in 1998. Dependent variables are the coded answers to the question regarding tax morale. With ordered probit he obtains the following estimates: ${ }^{.5)}$

$$
\begin{aligned}
& \mathrm{TM}=-0.00004 \mathrm{P}-0.001 \mathrm{FR}-0.010 \mathrm{TR}+0.104 \mathrm{DPR}+0.093 \mathrm{TRU} \\
& \begin{array}{llll}
(0.05) \quad(0.66) \quad(0.77) \quad(3.41) \quad(2.94) & 0
\end{array} \\
& +0.085 \mathrm{CA}+0.021 \mathrm{INC}+\ldots+\varepsilon, \\
& \text { (4.75) (0.96) }
\end{aligned}
$$

with:
TM tax morale;
P audit probability, approximated by the number of tax auditors per 1,000 tax- payers in each canton;
SST fine rate, approximated by the standard legal fine as a multiple of the evaded tax amount (in per cent) in the canton;
TR individual tax rate (in per cent);
INC the individual income class of the taxpayer (in 1,000 CHF);
DPR index for the extent of direct popular rights in the canton;
TRU measure of confidence in the courts and the legal system (ISSP);
CA degree of church attendance (ISSP).

The index of direct popular rights was developed by A. STUTZER (1999) and since then has often been employed. ${ }^{55)}$ It measures the degree of participation, with ' 1 ' reflecting the lowest and ' 6 ' the highest. It encompasses four sub-indices: (i) constitutional initiative, (ii) legislative initiative, (iii) legislative referendum, and (iv) fiscal referendum. Besides these, other variables such as age group, marital status and employment status are included in the regression equation.

52. The respective coefficients have opposite signs but are not significantly different from zero. Whether the difference is statistically significant has not been tested.

53. Similar results are presented in B. TORGLER (2007).

54. The numbers in parentheses are the absolute values of the z-statistics of the estimated parameters. - Similar results are provided by B. TORGLER and F. SCHNEIDER (2007). In contrast to here, they find a highly significant coefficient of the penalty tax.

55. See also the description of this index in the appendix of A. STUTZER (2003). 
[32] Out of these variables, only three are highly significant with a positive impact on tax morale: confidence in the courts and the legal system, the extent of direct popular rights, and the degree of church attendance. On the other hand, those variables which are assumed to be crucial for the economic theory of tax evasion, the audit probability and the fine rate, seem to have no impact at all on tax morale. The impacts of the other variables are also not statistically significant, even if the signs are plausible: a higher tax burden tends to provide more justification not to pay taxes, and higher income, usually providing more possibilities to evade taxes, which are exploited at least partially, motivates people - at least according to the theory of cognitive dissonance - to justify tax evasion by de-emphasizing its moral dimension.

[33] In order to investigate which of the four different instruments that are combined in the index of direct popular rights has an impact on tax morale, B. TORGLER (2005) uses the subindices for additional estimations. For the coefficients of the sub-indices he obtains the following results:

$$
\begin{array}{ll}
\text { Constitutional initiative } & 0.051 \\
\text { Legislative initiative } & 0.064 \\
\text { Legislative referendum } & 0.088 \\
\text { Fiscal referendum } & 0.090
\end{array}
$$

The coefficient of the constitutional initiative is at the 10 per cent level, that of the legislative initiative at the 5 per cent level, and those of the two referenda variables are at the 1 per cent level significantly different from zero. This indicates that a direct democratic instrument contributes more to raise tax morale, the more possibilities it provides for the citizens to control public expenditure as well as the possibilities to raise taxes.

[34] The question arises as to what extent these results might be generalised and hold for other countries as well. With respect to direct political rights it might be argued that except for the United States there is no other country in the world which has comparable direct rights at the state and local governmental levels, and for the U.S. there are no comparable studies available. Thus, generalisations might be problematic. On the other hand, there is no reason why citizens of other countries should behave totally differently. Thus, the hypothesis that the introduction and/or extension of direct popular rights might raise tax morale in other countries as well can be kept, at least preliminarily. With respect to trust in the legal system the situation is different. This has been investigated by B. TORGLER (2003). Using the World Value Survey data for European countries and the period from 1990 to 1993, he finds that, independent of the concrete estimation procedure, trust in the legal system always had a highly significant positive impact on tax morale. Using data from the Opinion Taxpayer Survey 1987, he obtained the same result for trust in the legal system. ${ }^{56)} \mathrm{He}$ obtains similar results

56. There, trust in public officials is the explanatory variable. On the Taxpayer Opinion Survey see L. HARRIS and AsSOCIATES (1988). For a survey about papers which set the theme 'trust' in relation to problems of public finances see J. SLEMROD (2003). 
also for Eastern European countries (2003a), Canada (2003b) as well as India and Japan (2004). Thus, it can be taken for granted that trust in the legal system has a positive impact on tax morale.

\section{Tax Morale and Tax Evasion}

[35] If we ask for the determinants of tax evasion, we might first think of the individual attributes of taxpayers such as, for example, age, education, employment and marital status. These variables are, however, rather uninteresting in this respect; they can hardly (or, at best, only in the very long term) be influenced by policy measures. If we use micro-data, in order not to bias the results, they are included in the regressions as control variables. For similar reasons, when using macro-data, it makes sense to use their means as controls. Besides these, there are individual data of interest, such as tax morale in particular, but also trust in the political and legal system, which however play hardly any role in the traditional economic approach to tax evasion. They depend on institutional conditions which can be changed and can, therefore, be influenced by policy measures. Thus, these institutional conditions have also to be represented in the estimation equations. Finally, there are the core variables of the traditional economic approach: tax rate, probability of detection, fine rate, as well as income.

[36] If we consider tax morale and other variables as determinants of tax evasion, we have to distinguish between direct and indirect impacts. It is, for example, a question of whether trust in the political system has an impact on tax compliance, independent of the moral qualification of tax evasion. On the other hand, it is open as to whether tax morale has an independent impact once we account for all other possible determinants. This could be tested in empirical analyses, but is hardly ever done.

[37] Moreover, there are only relatively few reliable investigations concerning the determinants of tax evasion. ${ }^{57)}$ Sometimes micro-data can be received from tax authorities. ${ }^{58)}$ These data have, however, their problems. Because even strong audits cannot detect all evasions, these data underestimate the actual amount. ${ }^{59)}$ Aggregate data can be constructed by comparing data for the national income (expenditure) from the national account with income data collected from tax declarations. ${ }^{60)}$ They rather overestimate evasion because not every nondeclared income is liable for taxation. ${ }^{61)}$ A third, but rather rare possibility, is tax amnesties. ${ }^{62)}$

57. Surveys are given, for example, by W.W. Pommerehne (1985), W.W. Pommerehne and H. WeCK-HANNEMANN (1992), J. ANDREONI, B. ERARD and J. FEINSTEIN (1998) as well as B. TORGLER (2001).

58. See, for example, Ch.T. Clotfelter (1983), J. SLEMrod (1985) or M. WEnZEL (2005a).

59. For this, see, for example, J. ANDREOnI, B. ERARD and J. FEINSTEIN (1998, p. 836).

60. See, for example, the two papers on Switzerland by H. WECK-HANNEMANN and W.W. PommereHnE (1989) as well as by B.S. FREY and L.P. FELD (2002).

61. For this, see, for example, J. SLEMROD and S. YITZHAKI (2000). - In Switzerland, such overestimations occur, for example, because private capital gains are not liable for taxation. They do, however, hardly count for a very large part of the difference between declared income and actual expenditure. 
Again the amount of evasion is underestimated because not all of those who have evaded taxes so far are willing to reveal their real income in case of such an amnesty.

[38] To circumvent these problems, survey data ${ }^{63)}$ and, more recently, data from experiments have been used. ${ }^{64)}$ But these data are also not without problems. Even under optimal conditions, hardly all of those who evade taxes will actually admit to this if asked. Moreover, if the effect of tax morale on tax compliance is to be investigated, it would be preferable to collect these two data sets independently of each other. Data from experiments do not have minor problems. The subjects can lose money, which might be interpreted as a fine, but, first, it is money given to them before and not 'own' (earned) income, and, second, the possible loss of a small amount of money can hardly be compared with a real fine or even imprisonment. Thus, the results should be taken seriously, but rather carefully interpreted.

[39] The main result is, however, unambiguous: tax morale is a main determinant of the willingness to pay taxes. ${ }^{65)}$ As was to be expected, the perceived fairness of the tax system plays an important role. ${ }^{66)}$ Moreover, there is also reversed causation from tax morale to the other determinants. As J.T. SCHOLZ and N. PINNEY (1995) have shown, the higher the perceived risk of being caught and punished when evading taxes, the higher the tax morale of an individual. Finally, reciprocity is crucial. Citizens are more willing to pay their taxes, the more they are convinced that their fellow citizens are doing the same. M. WENZEL (2005a) shows that a systematic bias might exist: they believe that others behave, on average, less morally than they do themselves. If this bias is corrected, tax evasion declines.

[40] Those studies which used real data from the tax authorities first asked for the impact of those determinants that play a role in the traditional model, in particular income and the marginal tax rate. The results are heterogeneous. For the United States, CH.T. Clotfelder (1983) finds a significant impact of both variables, but J. SLEMROD (1985) does not. E.M.R.A. ENGEL and J.R. HINES (2000) find a significant effect for the audit probability, but not for the marginal tax rate. Similarly contradictory results with respect to fines and the probability of detection have been derived for Switzerland. While H. WECK-HANNEMANN and W.W. POMMEREHNE (1989) do not find a significant impact of fines, B.S. FREY and L.P. FELD (2002) find a significant result. On the other hand, they get a significantly 'wrong' sign for the probability of detection.

62. See, for example, S.E. Crane and F. NOURZAD (1990) or J. ALM and W. BECK (1992).

63. See, for example, M. Ovriska and J. HudSON (2002), A. ForeSt and S.M. SHEFFrin (2002) or H. HAMMAR, S.C. JAGERS and K. NORDBLOM (2009). - On the measurement of tax compliance using survey data see also E. KIRCHLER and I. WAHL (2010).

64. See, for example, J. Alm, B.R. JACKSON and M. McKeE (1992), L. BosCO and L. Mittone (1997), L.P. FELD and R. TYRAN (2002), C.-G. PARK and J.K. HYUN (2003), R.C. CuMMings et al. (2009), as well as the survey by B. TORGLER (2002).

65. See, for example, P.M.J. Reckers, D.L. SANDERS and S.J. RoARK (1994), M. OvRISKA and J. HUDSON (2002) or D.D. BOBEK and R.C. HATFIELD (2003).

66. See, for example, A. Forest and S.M. SHEFFrin (2002) or D.D. BobeK and R.C. HATFIELD (2003). 
[41] The two latter papers again employ, besides the variables of the economic approach (and further controls), the extent of direct popular rights as explanatory variable. In the paper by B.S. FREY and L.P. FELD (2002), which we use as another example, treatment by the tax authorities is also taken into account. The proxy to represent this has been constructed on the basis of a survey among the cantonal tax authorities. ${ }^{67)}$ Thus, they take two aspects into account which are relevant for tax morale.

[42] With data for the 26 Swiss cantons and five years in the period from 1970 to 1995, they have 130 observations. They obtain the following result: ${ }^{68)}$

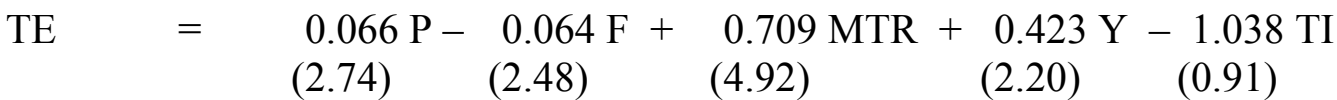

$$
\begin{aligned}
& -0.002 \text { Pop }-0.463 \text { A65 }-0.678 \mathrm{SSE}+0.403 \mathrm{SAS}-7.432 \text { Lat } \\
& \text { (1.94) (1.95) (2.61) (2.03) } \\
& \text { - 2.291 ID - 2.908 TypP - 5.725 RespP - 6.673 AutP + } \varepsilon \text {. } \\
& \text { (3.14) (3.49) (3.84) } \\
& \mathrm{R}^{2}=0.798
\end{aligned}
$$

with:
TE tax evasion;
P probability of detection;
F fine for tax evasion;
MTR maximum marginal tax rate;
$\mathrm{Y} \quad$ gross effective primary income per capita in 1,000 CHF;
TI dummy for tax indexation;
Pop cantonal population (in 1,000);
A65 percentage of people over 65 years in the population (in per cent);
SSE share of self-employed from total employment (in per cent);
SAE share of employment in the agricultural sector (in per cent);
Lat dummy for French and Italian speaking cantons;
ID index of direct popular rights;
TypV index for the procedure if no taxes are declared;

67. A problem with this data is, however, that - depending on the procedures in the different cantons - most taxpayers have no contact at all with the cantonal tax authorities but exclusively with the local tax authorities. This also holds for most of those taxpayers whose declarations are - for various reasons - not processed by local but by cantonal employees. On the other hand, cantonal tax authorities have an impact on local authorities, and some 'big' taxpayers might negotiate directly with the cantonal authorities.

68. Equation (4) in Table 2, p. 20, in B.S. FREY and L.P. FELD (2002). The numbers in parentheses are the absolute values of the t-statistics of the estimated parameters. The equation does not include a constant term because dummy variables for the five points in time are included. 
RespP dummy variable for a respectful procedure by the tax authorities;

AutP dummy variable for an authoritarian procedure by the tax authorities.

[43] As already mentioned, both variables of the traditional approach are significant, but the proxy for the probability of detection has the 'wrong' sign. This might indicate reversed causality: the higher the tax evasion is in a canton, the more it pays to employ additional tax collectors. That a high fine has a significant negative impact on tax evasion despite the fact that it has (according to the result of B. TORGLER (2005)) no impact on tax morale, reveals the difference between tax morale and tax compliance. Repressive measures can, as other studies show as well, reduce the amount of tax evasion, ${ }^{69)}$ but this does not imply that citizens revise their moral convictions. And whether this is the most efficient way to reduce tax evasion is, at least concerning the results of M. KUCHER and L. GÖTTE (1998), questionable.

[44] The index of direct democratic rights has a highly significant negative impact on the amount of tax evasion. Insofar, we see the same result as in the earlier papers by H. WECKHannemann and W.W. Pommerehne (1989) as well as W.W. Pommerehne and H. WeCKHANNEMANN (1996). Those variables which reflect the behaviour of the tax authorities are of particular interest in the paper by B.S. FREY and L.P. FELD (2002). ${ }^{70)}$ The more rigorous these authorities are if a declaration is missing, the more taxes are evaded. If the authorities detect an error in a declaration, respectful as well as authoritarian behaviour leads to less evasion, the former, one might guess, because trust in the cantonal tax authorities (and, more generally, in the public bureaucracy) is strengthened, the latter, because citizens fear repressive measures. $^{71)}$

[45] The big advantage of these investigations for Switzerland, be it those by W.W. POMMEREHNE and H. WECK-HANNEMANN or those by L.P. FELD and B.S. FREY is that the independent variables are constructed using official data without using indicators of tax morale; the condition that dependent and explanatory variables have to be constructed independently holds. Thus, for testing whether tax morale has an impact on tax compliance and, consequently, also on the size of the shadow economy, these results are much more reliable than those of the model approach. We can, therefore, take for granted that tax morale has a significantly positive impact on tax compliance. While we can trust in this qualitative result, we have to be somewhat more cautious with respect to the quantitative (numerical) results. The reason for this is that estimates regarding the amount of tax evasion as well as the size of the shadow economy differ widely, depending on the measurement method. ${ }^{72)}$ Taking Switzerland as an

69. See, for example, L. LeDERMANn (2003).

70. See for this also L.P. FELD and B.S. FREY (2001).

71. The estimated impact of respectful behaviour might, however, also reflect reversed causality. The less taxes are evaded in a canton, the less the tax collectors might feel induced to be very strict. - In a further equation using interaction terms, B.S. FREY and L.P. FELD (2002, p. 20, equation (5)) try to show that authoritarian behaviour of the tax authorities is more likely in 'representative' and respectful behaviour is more likely in 'direct' democracies. The results are, however, not so clear-cut that this conclusion can be drawn.

72. For a description of the different methods, see, for example, F. SCHNEIDER (2001). 
example, Table 1 shows different estimates for the period covered by B.S. FREY and L.P. FELD (2002). While the results for the model and the currency approaches are rather similar, the comparison of income and expenditure leads to rather different figures, which are about three to four times higher. These differences are too large to be only a result of the overestimation by the latter method discussed above. Thus, not the qualitative results, but the quantitative figures derived by these approaches (and used in further studies) should be interpreted rather cautiously.

\begin{tabular}{|c|c|c|c|}
\hline \multicolumn{4}{|c|}{$\begin{array}{c}\text { Table 1: Size of the Swiss Shadow Economy (Amount of Undeclared Income) } \\
\text { (as percentage of the official economy (total income)) }\end{array}$} \\
\hline Year & Method & Size & Source \\
\hline 1978 & Model approach & 4.3 & $\begin{array}{l}\text { H. WECK, W.W. POMMEREHNE and B.S. FREY } \\
(1984, \text { p. 67) }\end{array}$ \\
\hline $1990 / 93$ & Model approach & 6.9 & F. SCHNEIDER $(2001$, p. 22) \\
\hline 1980 & Currency approach & 6.3 & $\begin{array}{l}\text { H. WECK, W.W. POMMEREHNE and B.S. FREY } \\
(1986 \text {, p. 32) }\end{array}$ \\
\hline $1990 / 93$ & Currency approach & 6.9 & F. SCHNEIDER and D. ENSTE (2000, p. 102). \\
\hline 1970/95 & $\begin{array}{l}\text { Comparison of } \\
\text { income declared } \\
\text { and expenditure }\end{array}$ & 23.48 & B.S. FREY and L.P. FELD (2002, p. 36). \\
\hline
\end{tabular}

\section{Concluding Remarks}

[46] Taking all the results together, despite all the problems discussed above, not only theoretical considerations, but also empirical investigations show that tax morale has an important impact on the behaviour of taxpayers and, therefore, also on the size of the shadow economy. Tax morale, on the other hand, depends on institutional conditions, but also, on how citizens are treated by tax authorities, by their trust in the political and the legal system, and by the extent of direct popular rights: the more citizens can take part in fiscal decisions, the more they are willing to make their individual contributions in order to finance the government. ${ }^{73)}$

[47] Given the qualifications discussed in Section 2, paying taxes is considered being a moral duty of citizens. Thus, this discussion is about the duties of the individual and not about their rights. Not long ago, at the beginning of the seventies, people were still rather sceptical about such arguments. Then, the emancipation of the individual was the main topic, and the accent was on rights which - according to liberal conviction - are inalienable properties of the individual. In contrast to this, when taking up office on January 20, 1961, JOHN F. KENNEDY

73. See also R.M. BIRD, J. MARTINEZ-VAzQueZ and B. TORGLER (2007) who show for developing countries that accountability of the government has a positive and corruption a negative impact on tax effort. 
had already made the following famous statement to his American co-citizens: "Don't ask what your country can do for you, ask what you can do for your country!",74) But the political philosophy of that time also mainly asked for the individuals' rights and under which conditions these rights might be restricted and asked much less for the duties of the individuals to their community. ${ }^{75)}$

[48] In the meantime, the situation has changed. Firstly, somewhat more than ten years ago, in addition to the catalogue of human rights, a catalogue of human duties was presented to the international discussion. Of course, opinions about this enterprise are mixed. ${ }^{76)}$ Secondly, the problem of citizens' duties is an important question discussed today within political communitarism, a movement which is strongly influenced by AMITAI ETZIONI. ${ }^{77)}$ The first version of the 'Communitarian Platform' developed by him contains the statement: "Paying one's taxes and encouraging others to pay their fair share ... are fully obligatory." (1993, p. 18. ${ }^{78)}$ The solution he strives for, to use moral suasion in order to encourage citizens to have more civic duty might, however, not be very successful. The same holds for the hope of W. GAERTNER, that "the sense for fairness, the feeling for justice as well as attention for and the compliance with laws" might be encouraged "by investment in the moral education of all members of the society". (1988, p. 127.) Most such attempts to influence the preferences have hardly been successful in the past.

[49] On the other hand, at the beginning of his "Theory of Moral Sentiment", ADAM SMITH $(1759$, p. 1) tells us that human beings are also moral beings, i.e., not totally reserved against moral arguments. How open they are for such arguments might depend on the institutional conditions under which they act, and recognising this is a precondition for really understanding the empirical results presented above. In order to reduce tax evasion and following the economic approach, the appropriate way is to set incentives so that citizens have as strong a motivation as possible to pay taxes. However, as M.G. Allingham and A. SANDmo (1972) have already shown, a strategy which solely relied on these incentives could only be successful if the taxpayers were extremely risk averse, something they hardly are now. ${ }^{79)}$ That citizens pay considerably more taxes than is compatible with only acting in narrow self-interest indicates that they are more strongly motivated by moral reasons than is suggested by the (standard) economic model of behaviour. Because this depends on societal conditions, policy can still be successful even if

74. See for this J.F. KENNEDY (1962, p. 28).

75. This holds, for example, for the basic works of the 'new contractarians' R. NozICK (1974) and J.M. BUCHANAN (1975). J. RAWLS (1971), on the other hand has a chapter about "duty and obligation" (pp. 368ff.).

- For an introduction into these theories see, for example, S. GORDON (1976).

76. See for this: Allgemeine Erklärung der Menschenpflichten, DIE ZEIT No. 41 October 3, 1997; H. SCHMIDT, Zeit von den Pflichten zu sprechen, ibid, pp. 17f.; as well as the discussion following the article in this newspaper.

77. See, for example, A. ETZIONI (1993, 1995).

78. See also http://www.gwu.edu/ ccps/platformtext.html (16/03/10).

79. For more realistic theoretical models including psychological costs or ethical preferences see, for example, J. SCHNELLENBACH $(2006,2007)$ or J.G. EISENHAUER (2008). 
it is (correctly) assumed that it is hardly possible to directly influence the preferences of the individual. If the willingness to pay taxes is to be enforced, a responsible use of tax revenue by the public authorities is necessary as well as a partnership relation (and not a magisterial one) between them. Moreover, federal structures might be strengthened by providing real tax autonomy to the lower governmental levels as well as giving citizens at least some direct political rights with respect to the determination of public finances. In all these respects, however, especially with respect to federal structure and direct popular rights, much could be done in many countries. The situation could be improved, i.e., tax evasion (and, correspondingly, also the shadow economy) could be reduced if there were real attempts to do so.

\section{Zusammenfassung}

Was sind die Bedingungen für eine moralische Rechtfertigung der Besteuerung, und welche Auswirkungen hat diese auf die Steuerehrlichkeit. Diese Fragen sind nicht nur für Ökonomen und Philosophen von wissenschaftlichem Interesse, sondern sie haben auch erhebliche praktische Relevanz, da die Bereitschaft, Steuern zu zahlen, sehr davon abhängen kann, ob man die Erhebung der Steuern als moralisch gerechtfertigt ansieht oder nicht. In dieser Arbeit werden zuerst theoretische Argumente über die Rolle der Steuermoral und die Frage, wann Steuerhinterziehung moralisch gerechtfertigt sein könnte, diskutiert. Dann wird aufgezeigt, wie die Steuermoral gemessen werden kann. Danach werden empirische Untersuchungen vorgestellt, zunächst für den Einfluss der Steuermoral auf die Schattenwirtschaft, dann bezüglich der Determinanten der Steuermoral und schliesslich über den Zusammenhang zwischen Steuermoral und Steuerhinterziehung. Dabei zeigt sich, dass für eine hohe Steuermoral institutionelle und kulturelle Faktoren mindestens so wichtig sind wie die üblichen ökonomischen Anreize, seien dies die Höhe der Besteuerung, die Höhe der zu erwartenden Strafe, falls die Hinterziehung aufgedeckt wird, oder auch die Wahrscheinlichkeit dieser Aufdeckung. Die Arbeit schliesst mit Überlegungen zu Rechten und Pflichten in bezug auf die Besteuerung. 


\section{References}

M.G. Allingham and A. SANDmo (1972), Income Tax Evasion: A Theoretical Analysis, Journal of Public Economics 1 (1972), pp. 323 - 338.

J. ALM and W. BECK (1993), Tax Amnesties and Compliance in the Long-Run: A Time Series Analysis, National Tax Journal 46 (1993), pp. 53 - 60.

J. AlM and B. Torgler (2006), Cultural Differences and Tax morale in the United States and in Europe, Journal of Economic Psychology 27 (2006), pp. 234 - 246.

J. ALM, B.R. JACKSON and M. MCKEE (1992), Estimating the Determinants of Taxpayer Compliance with Experimental Data, National Tax Journal 45 (1992), pp. 107 - 114.

J. Alm, G.H. MCClelland and W.D. SchUlze (1992), Why Do People Pay Taxes?, Journal of Public Economics 48 (1992), pp. 21 - 38.

J.B. ANDREONI, B. ERARD and J. FEINSTEIN (1998), Tax Compliance, Journal of Economic Literature 36 (1998), pp. $818-860$.

A. BALESTRINO (2009), Tax Avoidance, Endogenous Social Norms, and the Comparison Income Effect, University of Pisa, Centre for Household, Income, Labour and Demographic Economics, ChilD Working Paper No. 15/2009, June 2009.

G. BArone and S. Mochetti (2009), Tax Morale and Public Spending Inefficiency, Banca D'Italia, Working Paper No. 732, November 2009.

R.M. Bird, J. MARTinez-VAzQueZ and B. TORgLeR (2007), Tax Effort: The Impact of Corruption, Voice and Accountability, CREMA Working paper No. 2007-13, Basel 2007.

CH. B. BlanKarT (1980), Ökonomie der öffentlichen Unternehmen, Vahlen, München 1980.

D.D. BoBEK and R.C. HATFIELD (2003), An Investigation of the Theory of Planned Behavior and the Role of Moral Obligation in Tax Compliance, Behavioral Research in Accounting 15 (2003), pp. $13-38$.

M. BordignON (1993), A Fairness Approach to Income Tax Evasion, Journal of Public Economics 52 (1993), pp. $345-362$.

M. Boskin and E. SHESHINSKI (1978), Optimal Redistributive Taxation When Individual Welfare Depends upon Relative Income, Quarterly Journal of Economics 92 (1978), pp. 589 - 601.

L. BosCO and L. MitTone (1997), Tax Evasion and Moral Constraints: Some Experimental Evidence, Kyklos 50 (1997), pp. $297-324$.

T. BREUSCH (2005), Estimating the Underground Economy Using MIMIC Models, mimeo, Australian National university, Canberra, November 2005.

D.J. Broome (1990), Fairness, Proceedings of the Aristotelian Society 91 (1990), pp. 87 - 102; reprinted in: A.P. HAMLIN (ed.), Ethics and Economics, Volume II, Edward Elgar, Cheltenham (UK) et al, pp. $433-447$.

J.M. Buchanan (1967), Public Finance in Democratic Process: Fiscal Institutions and Individual Choice, University of North Carolina Press, Chapel Hill 1967.

J.M. BuCHANAN (1975), The Limits of Liberty, University of Chicago Press, Chicago 1975.

J.M. Buchanan (1987), The Constitution of Economic Policy, American Economic Review 77 (1987), pp. $243-250$.

K. Chaudhuri, F. Schneider, and S. Chattopadhyay (2006), The size and development of the shadow economy: An Empirical Investigation from States of India, Journal of Development Economics 80 (2006), pp. $428-443$.

Ch.T. Clotfelter (1983), Tax Evasion and Tax Rates: An Analysis of Individual Returns, Review of Economics and Statistics 65 (1983), pp. 363 - 373. 
S.E. CRANE and F. NourZAD (1990), Tax Rates and Tax Evasion: Evidence from California Amnesty Data, National Tax Journal 43 (1990), pp. 189 - 199.

M.T. Crowe (1944), The Moral Obligation of Paying Just Taxes, The Catholic University of America Studies in Sacred Theology No. 84, 1944.

R.C. Cummings, J. Martinez-Vasquez, M. McKee and B. Torgler (2009), Tax morale Affects Tax Compliance: Evidence from Surveys and an Artefactual Field Experiment, Journal of Economic Behaviour and Organization 70 (2009), pp. 447 - 457.

R. DELL' ANNO and F. SCHNEIDER (2006), Estimating the Underground Economy Using MIMIC Models: A response to T. Breusch's Critique, Johannes Keppler University of Linz, Department of Economics, Working Paper No. 0607, July 2006.

D. DORN, J.A.V. FISCHER, G. KIRCHGÄSSNER and A. SOUSA-POZA (2008), Direct democracy and Life satisfaction Revisited: New Evidence for Switzerland, Journal of Happiness Studies 9 (2008), pp. $227-255$.

R. EASTERLIN (2001), Income and Happiness: Towards a Unified Theory, Economic Journal 111 (2001), pp. $465-484$.

J.E. EISENHAUER (2008), Ethical Preferences, Risk Aversion, and Taxpayer Behavior, Journal of Socio-Economics 37 (2008), pp. $45-63$.

E.M.R.A. ENGEL and J.R. HINES (2000), Understanding Tax Evasion Dynamics, Econometric Society World Congress 2000 Contributed Paper 1117.

A. Etzioni (1993), The Spirit of Community: Rights, Responsibilities, and the Communitarian Agenda, Crown Publishers, New York 1993.

A. ETZIONI (1995), On Restoring the Moral Voice, in: A. EtZIONI (ed.), Rights and the Common Good: The Communitarian Perspective, St. Martin's Press, New York 1995, pp. $271-276$.

L.P. FELD and B.S. FREY (2001), Trust Breeds Trust: How Taxpayers are Treated, Economics of Governance 2 (2001), pp. $87-99$.

L.P. FeLD and J.-R. TYRAN (2002), Tax Evasion and Voting: An Experimental Analysis, Kyklos 55 (2002), pp. $197-222$.

L.P. Feld, B. Torgler and B. Dong (2008), Coming Closer? Tax morale, Deterrence and Social Learning after German Unification, CREMA Working Paper No. 2008-9, Basel, 2008.

A. FOREST and S.M. SHEFFrIN (2002), Complexity and Compliance: An Empirical Investigation, $\mathrm{Na}$ tional Tax Journal 55 (2002), pp. 75 - 88.

B.S. FREY and L.P. FELD (2002), Deterrence and Morale in Taxation: An Empirical Analysis, CESifo Working Paper No. 760, München, August 2002.

B.S. FREY and G. KIRCHGÄSSNER (2002), Demokratische Wirtschaftspolitik: Theorie und Anwendung, Vahlen, München, $3^{\text {rd }}$ edition 2002.

B.S. FREY and B. TORGLER (2007), Tax morale and Conditional Cooperation, Journal of Comparative Economics 35 (2007), pp. 136 - 159.

B.S. FREY and H. WECK-HANNEMANN (1984), The Hidden Economy as an Unobserved Variable, European Economic Review 26 (1984), pp. 33 - 53.

W. GAERTNER (1988), Untergrundwirtschaft, Steuerhinterziehung und Moral, in: H. HeSSE (ed.), Wirtschaftswissenschaft und Ethik, Duncker und Humblot, Berlin 1988, pp. 109 - 130.

J.K. Galbraith (1958), The Affluent Society, Houghton Mifflin, Boston 1958.

S. GoRdon (1976), The New Contractarians, Journal of Political Economy 84 (1976), pp. 573 - 590.

M.J. GRAETZ and L.L. WiLDE (1985), The Economics of Tax Compliance: Facts and Fantasy, National Tax Journal 38 (1985), pp. 355 - 363. 
W. GÜTH, V. LeVATI and R. SAUSGRUBer (2005), Tax morale and (De-)Centralisation: An Experimental Study, Public Choice 125 (2005), pp. 171 - 188.

H. HAMMAR, S.C. JAGERS and K. NORDBlOM (2009), Perceived Tax Evasion and the Importance of Trust, Journal of Socio-Economics 38 (2009), pp. 238 - 245.

J.C. HARSANYI (1975), Can the Maximim Principle Serve as a Basis of Morality?, A Critique of John Rawls's Theory, American Political Science Review 69 (1975), pp. 594 - 606.

L. HARRIS and AssociateS (1988), 1987 Taxpayer Opinion Survey, Conducted for the U.S. Internal Revenue Service, Internal Revenue Service Document No. 7292, Washington D.C. 1988.

R. HAUSER (1974), Gerechtigkeit, in: J. RITTER (ed.), Historisches Wörterbuch der Philosophie, Band 3, Schwabe und Co, Basel/Stuttgart 1974, pp. 329 - 335.

O. HÖFFE (1987), Politische Gerechtigkeit: Grundlegung einer kritischen Philosophie von Recht und Staat, Suhrkamp, Frankfurt 1987.

O. HÖFFE (1990), Gerechtigkeit als Tausch: Ein ökonomisches Prinzip für die Ethik, in: P. ULRICH (ed.), Auf der Suche nach einer modernen Wirtschaftsethik: Lernschritte zu einer reflexiven Ökonomie, Haupt, Bern 1990, pp. 91 - 102.

O. HÖFFE (1994), Tauschgerechtigkeit und korrektive Gerechtigkeit: Legitimationsmuster für Staatsaufgaben, in: D. GRIMM (ed.), Staatsaufgaben, Nomos, Baden-Baden 1994, pp. 713 - 737.

B. HoOKer (2005), Fairness, Ethical Theory and Moral Practice 8 (2005), pp. 329 - 352.

R. Inglehart et al. (2004), Human Beliefs and Values: A Cross-Cultural Sourcebook Based on the 1999 - 2002 Values Surveys, Siglo XXI Editores, Mexico 2004.

N. IRELAnd (2001), Optimal Tax in the Presence of Status Effect, Journal of Public Economics 81 (2001), pp. $193-212$.

K.G. JÖRESKOG and M. VAN THILLO (1973), LISREL: A General Computer Program for Estimating a Linear Structural Equation System Involving Multiple Indicators of Unobserved Variables, University of Uppsala, Department of Statistics, Research Report 73-5.

D. KAHNEMANN, J.L. KNETSCH and R.H. ThaLeR (1986), Fairness and the Assumptions of Economics, Journal of Business 59 (1986), pp. S285 - S300.

J.F. Kennedy (1962), To Turn the Tide: The Major Addresses and Statements of President John F. Kennedy, Harper and Brothers, New York 1962.

G. KIRCHGÄSSNER (1984), Verfahren zur Erfassung des in der Schattenwirtschaft erarbeiteten Sozialprodukts, Allgemeines Statistisches Archiv 68 (1984), pp. 378 - 405.

G. KIRCHGÄSSNER (2003), Moralische Aspekte der Besteuerung, in: M. ROSE (ed.), Integriertes Steuer- und Sozialsystem, Physica, Heidelberg 2003, pp. 215 - 241.

G. KIRCHGÄSSNER (2010), On Minimal Morals, forthcoming in: European Journal of Political Economy 25 (2010).

G. KIRCHGÄSSNER and W.W. POMMEREHNE (1992), Approaches to Explain Fiscal Redistribution in Democracy, mimeo, Hochschule St. Gallen, 1992.

E. KIRCHLER and I. WAHL (2010), Tax Compliance Inventory TAX-I: Designing an Inventory for Surveys of Tax Compliance, forthcoming in: Journal of Economic Psychology 2010.

W. KoCH (1981), Finanzwissenschaft I: Geschichte, in: W. ALBERS et al. (eds.), Handwörterbuch der Wirtschaftswissenschaft, Band 3, Gustav Fischer et al., Stuttgart et al. 1981, pp. 211 - 234.

J. KonOw (2003), Which is the Fairest One of All?, A Positive Analysis of Justice Theory, Journal of Economic Literature 41 (2003), pp. 1186 - 1237.

M. KUCHER and L. GÖTTE (1998), Trust Me: An Empirical Analysis of Taxpayer Honesty, Finanzarchiv 54 (1998), pp. $429-444$. 
I. Lago-Peñas and S. Lago-Peñas (2008), The Determinants of Tax Morale in Comparative Perspective: Evidence from a Multilevel Analysis, Instituto de Estudios Fiscales, Madrid, Working Paper No. 2/08, January 2008.

L. LEDERMANN (2003), The Interplay Between Norms and Enforcement in Tax Compliance, Georg Mason University, Law and Economics Working Paper No. 03-12.

R.W. MCGEe (2005), The Ethics of Tax Evasion: A Survey of International Business Academics, Paper presented at the $60^{\text {th }}$ International Atlantic Economic Conference, New York, October $6-9$, 2005.

R.W. MCGEE (2006), Three Views on the Ethics of Tax Evasion, Journal of Business Ethics 67 (2006), pp. $15-35$.

R.W. McGee (2008), Taxation and Public Finance in Transition and Developing Countries, Springer, New York et al. 2008.

R.A. MusgraVe and P.B. Musgrave (1984), Public Finance in Theory and Practice, McGraw-Hill, New York et al., $4^{\text {th }}$ edition 1984.

R. NOZICK (1974), Anarchy, State, and Utopia, Basil Blackwell, Oxford 1974.

W.E. OATES (1985), Searching for Leviathan: An Empirical Study, American Economic Review 75 (1985), pp. $748-757$.

M. ORVISKA and J. HudSON (2002), Tax Evasion, Civic Duty and the Law Abiding Citizen, European Journal of Political Economy 19 (2002), pp. 83 - 102.

C.-G. PARK and J.K. HYUN (2003), Examining the Determinants of Tax Compliance by Experimental Data: A Case of Korea, Journal of Policy Modeling 25 (2003), pp. 673 - 684.

W.W. POMMEREHNE (1985), Was wissen wir eigentlich über Steuerhinterziehung?, International Review of Economics and Business 32 (1985), pp. 1155 - 1186.

W.W. Pommerehne and H. WeCK-HANNEMANN (1992), Steuerhinterziehung: Einige romantische, realistische und nicht zuletzt empirische Befunde, Zeitschrift für Wirtschafts- und Sozialwissenschaften 112 (1992), pp. 433 - 466.

W.W. POMMEREHNE and H. WeCK-HANNEMANN (1996), Tax Rates, Tax Administration and Income Tax Evasion in Switzerland, Public Choice 88 (1996), pp. 161 - 170.

W.W. PommereHNE, A. HART and B.S. FreY (1994), Tax morale, Tax Evasion and the Choice of Instruments in Different Political Systems, Public Finance 49 (1994, Supplement), pp. 52 - 69.

W.W. PommereHNE, A. HART and L.P. FeLD (1997), Steuerhinterziehung und ihre Kontrolle in unterschiedlichen politischen Systemen, Homo Oeconomicus 14 (1997), pp. 469 - 478.

A. PRINZ (2004), Steuermoral und Religiosität in Ost- und Westdeutschland, Schmollers Jahrbuch 124 (2004), pp. $511-537$.

J. RAWLs (1971), A Theory of Justice, Harvard University Press, Cambridge (Mass.) 1971.

P.M.J. RECKERS, D.L. SANDERS und S. ROARK (1994), The Influence of Ethical Attitudes on Taxpayer Compliance, National Tax Journal 47 (1994), pp. 825 - 836.

W. Richter (2010), Geplante Steuerhinterziehung und ihre effiziente Bestrafung, in: B.-A. WICKSTRÖM (ed.), Finanzpolitik und Schattenwirtschaft, Duncker und Humblot, Berlin 2010, pp. 67 92.

G. SCHMÖLDERS (1951), Finanzpsychologie, Finanzarchiv 13 (1951), pp. 1 - 36.

G. SCHMÖLDERS (1981), Finanz- und Steuerpsychologie, in: W. ALBERS et al. (eds.), Handwörterbuch der Wirtschaftswissenschaft, Band 3, Gustav Fischer et al., Stuttgart et al. 1981, pp. 121 - 133.

F. SCHNEIDER (2001), What Do We Know About the Shadow economy: Evidence from 21 OECD Countries, World Economics 2 (2001), pp. $19-32$. 
F. SCHNEIDER (2005), Shadow Economies Around the World: What Do We Really Know?, European Journal of Political Economy 21 (2005), pp. 598 - 642.

F. SCHNEIDER and E. ENSTE (2000), Shadow Economies: Size, Causes, and Consequences, Journal of Economic Literature 38 (2000), pp. 77 - 144.

F. SCHNEIDER and E. EnSTE (2002), The Shadow Economy: An International Survey, Cambridge University Press, Cambridge (UK) 2002.

J. SChnellenbach (2006), Tax morale and the Taming of Leviathan, Constitutional Political Economy 17 (2006), pp. 117 - 132.

J. SCHNellenbaCh (2007), Tax morale and the Legitimacy of Economic Policy, Homo Oeconomicus 17 (2007), pp. $21-45$.

E. SCHÖBEL (2005), Otto Veit and Subsequent Developments of Tax Morality, in: J.G. BACKHAUS (ed.), Essays on Fiscal Sociology, Peter Lang, Bern et al. 2005, pp. $187-210$.

J.T. SCHOLZ and N. PINNEY (1995), Duty, Fear, and Tax Compliance: The Heuristic Basis of Citizenship Behavior, American Journal of Political Science 39 (1995), pp. 490- 512.

P. SELMER (1986), Kein Recht zum Steuerboykott wegen Rüstungsausgaben, Juristische Schulung (JUS) 20 (1986), p. 226.

H.-W. SINN (1996), Social Insurance, Incentives and Risk Taking, International Tax and Public Finance 3 (1996), pp. $259-280$.

H.-W. SinN (1997), Das Selektionsprinzip und der Steuerwettbewerb, in: A. OBERHAUSER (ed.), Fiskalföderalismus in Europa, Duncker und Humblot, Berlin 1997, pp. 9 - 60.

J. Slemrod (1985), An Empirical Test for Tax Evasion, Review of Economics and Statistics 67 (1985), pp. $232-238$.

J. SLemrod (2003), Trust in Public Finance, in: S. CNOSSEN and H.-W. SINN (eds.), Public Finance and Public Policy in the New Century, MIT Press, Cambridge (Mass.) 2003, pp. 49 - 88.

J. SLEMrod and Y. YitzHAKI (2000), Tax Avoidance, Evasion, and Administration, NBER Working Paper No. 7473, January 2000.

A. SMITH (1759), Theory of Moral Sentiments, Millar, London 1759.

A. StUtZer (1999), Demokratieindizes für die Kantone der Schweiz, IEW Working Paper No. 23, Zürich, Oktober 1999.

A. STUTZER (2003), Eine ökonomische Analyse menschlichen Wohlbefindens, Shaker, Aachen 2003.

V. TANZI (1993), A Primer on Tax Evasion, IMF Staff Papers 40 (1993), pp. 807 - 829.

K. TIPKE and J. LANG (1973), Steuerrecht, Otto Schmid, Köln, $15^{\text {th }}$ edition 1996.

B. TORGLER (2005), Tax morale and Direct Democracy, European Journal of Political Economy 21 (2005), pp. $525-531$.

B. TORgler (2001), What Do We Know about Tax morale and Tax Compliance?, International Review of Economics and Business 48 (2001), pp. 395 - 419.

B. TORGLER (2002), Speaking to Theorists and Searching for Facts: Tax morale and Tax Compliance in Experiments, Journal of Economic Surveys 15 (2002), pp. 657 - 683.

B. Torgler (2003), Tax morale, Rule-Governed Behaviour and Trust, Constitutional Political Economy 14 (2003), pp. $119-140$.

B. TORgler (2003a), Tax morale in Transition Countries, Post-Communist Economies 15 (2003), pp. $357-381$.

B. TORgler (2003b), To Evade Taxes or Not to Evade: That Is the Question, Journal of Socio-Economics 32 (2003), pp. $283-302$. 
B. TORgLer (2004), Tax morale in Asian Countries, Journal of Asian Economics 15 (2004), pp. 237 266.

B. TORgler (2005), Tax morale and Direct Democracy, European Journal of Political Economy 21 (2005), pp. $525-531$.

B. TORgler (2005a), Tax morale and Fiscal Autonomy: Evidence from Germany, Public Finance and Management 5 (2005), pp. 460 - 485.

B. TORGLER (2006), The Importance of Faith: Tax morale and Religiosity, Journal of Economic Behavior and Organization 61 (2006), pp. $81-109$.

B. TORGLER (2007), The Impact of Direct Democracy and Local Autonomy on Tax morale in Switzerland, The School of Economics and Finance, Queensland University of Technology, Institute of Local Public Finance, Brisbane, December 2007.

B. Torgler and Ch.A. Schaltegger (2006), Tax Morale: A Survey with a Special Focus on Switzerland, Schweizerische Zeitschrift für Volkswirtschaft und Statistik 142 (2006), pp. 395 - 425.

B. TORGLER and F. SCHNEIDER (2007), What Shapes Attitudes Toward Paying Taxes? Evidence from Multicultural European Countries, Social Science Quarterly 88 (2007), pp. 228 - 245.

B. TORGLER and F. SCHNEIDER (2009), The Impact of Tax morale and Institutional Quality on the Shadow Economy, Journal of Economic Psychology 30 (2009), pp. 443 - 470.

B. TORGLER and W. Werner (2005), Tax morale and Fiscal Autonomy: Evidence from Germany, Public Finance and Management 5 (2005), pp. 460 - 485.

T.R. TYLER (1997), Procedural Fairness and Compliance with the Law, Schweizerische Zeitschrift für Volkswirtschaft und Statistik 133 (1997), pp. 219 - 240.

P. VERBOON and M. VAN DiJKe (2007), A Self-Interested Analysis of Justice and Tax Compliance: How Distributive Justice Moderates the Effect of Outcome Favorability, Journal of Economic Psychology 28 (2007), pp. $704-727$.

M. Vihanto (2003), Tax Evasion and the Psychology of the Social Contract, Journal of Socio-Economics 32 (2003), pp. $111-125$.

H. WECK (1983), Schattenwirtschaft: Eine Möglichkeit zur Einschränkung der öffentlichen Verwaltung?, Lang, Frankfurt 1983.

H. WeCK-HANNEMANN and W.W. POMMEREHNE (1989), Einkommensteuerhinterziehung in der Schweiz: Eine empirische Analyse, Schweizerische Zeitschrift für Volkswirtschaft und Statistik 125 (1989), pp. $515-556$.

H. WeCK, W.W. POMMEREHNE and B.S. FrEY (1984), Schattenwirtschaft, Vahlen, München 1984.

H. WeCK, W.W. Pommerehne and B.S. FreY (1986), Die heimliche Wirtschaft: Struktur und Entwicklung der Schattenwirtschaft in der Schweiz, Paul Haupt, Bern und Stuttgart 1986.

M. Wenzel (2004), An Analysis of Norm Processes in Tax Compliance, Journal of Economic Psychology 25 (2004), pp. $213-228$.

M. Wenzel (2005), Motivation or Rationalisation? Causal Relations Between Ethics, Norms, and Tax Compliance, Journal of Economic Psychology 26 (2005), pp. 491 - 508.

M. WenZEL (2005a), Misperceptions of Social Norms About Tax Compliance: From Theory of Intervention, Journal of Economic Psychology 26 (2005), pp. 862 - 883.

K. WICKSELL (1896), Finanztheoretische Untersuchungen, Gustav Fischer, Jena 1896.

S.-Y. WU and M.-J. Teng (2005), Determinants of Tax Compliance: A Cross-Country Analysis, Finanzarchiv 61 (2005), pp. $393-417$. 